\section{jurnal material kedokteran gigi}

p-ISSN 2302-5271 e-ISSN 2685-0214

DOI 10.32793/jmkg.v8i1.335
Sitotoksisitas Kombinasi Seng-oksida dan Ekstrak Curcuma longa Terhadap Fibroblas Gingiva Manusia

\author{
Vina Aprilia, Asti Meizarini, Titien Hary Agustantina \\ Departemen Material Kedokteran Gigi \\ Fakultas Kedokteran Gigi Universitas Airlangga \\ Surabaya, Indonesia
}

\section{ABSTRAK}

Penggunaan seng oksida - eugenol sebagai dressing periodontal masih dipermasalahkan, karena sifat eugenol yang toksik, dan Curcuma longa Linn sebagai herbal alami yang aman diharapkan dapat menggantikan fungsi eugenol. Penelitian sebelumnya telah membuktikan bahwa kombinasi seng oksida dengan ekstrak Curcuma longa cair, memiliki sifat antibakteri dan penggunaannya sebagai dressing terbukti mempercepat penyembuhan luka in vivo. Bahan yang diaplikasikan dalam rongga mulut harus tidak beracun dan bersifat biokompatibel, oleh karena itu diperlukan uji sitotoksisitas. Untuk mengetahui sitotoksisitas kombinasi seng oksida dan ekstrak Curcuma longa pada sel fibroblas gingiva manusia. Uji sitotoksisitas kombinasi serbuk seng oksida dan ekstrak Curcuma longa dilakukan dengan perbandingan 1: 1 (kelompok $A$ ) dan 2: 1 (kelompok B), ekstrak Curcuma longa cair (kelompok C) dan serbuk seng oksida (Kelompok D), yang dilakukan pada sel kultur fibroblas gingiva manusia (kepadatan 3-5×103) dalam microplate 96 wells. Analisis sitotosisitas dilakukan menggunakan esai MTT dengan parameter IC50. Uji statistik menggunakan oneway Anova dan LSD. Hasil: Jumlah sel hidup dalam kelompok $A=64,819 \%$, kelompok $B=59,452 \%$, kelompok $C=52,859 \%$ dan kelompok $D=60,52 \%$. Tidak ada perbedaan yang signifikan antara kelompok $A, B, D$ tetapi berbeda signifikan dengan kelompok $C$. Kombinasi seng oksida dengan ekstrak Curcuma longa rasio 1: 1 dan 2: 1, serbuk seng oksida dan ekstrak cair Curcuma tidak toksik untuk fibroblas gingiva manusia pada IC50.

Kata kunci: Curcuma longa, sitoksisitas, seng oksida

\section{Zinc oxide and Curcuma longa Extract Combination Cytotoxicity Toward Human Gingival Fibroblast}

\section{ABSTRACT}

The use of zinc oxide - eugenol as periodontal dressing is controversial due to the toxic nature of eugenol and Curcuma longa Linn as a safe natural herbal, is expected to replace eugenol function. Previous research has proven that the combination of zinc oxide with Curcuma liquid extract has an antibacterial properties and the use of those as wound dressing
Asti Meizarini

Email:asti-m@fkg.unair.ac.id 
through in vivo studies proved to accelerate wound healing. The ingredients applied to the oral cavity must be non-toxic and biocompatible, therefore cytotoxicity testing is required. To determine the cytotoxicity of zinc oxide and Curcuma longa extract combination on human gingival fibroblast cells. Cytotoxicity test of combination of zinc oxide powder with Curcuma liquid extract was done at ratio of 1: 1 (group $A$ ) and 2: 1 (group B), Curcuma liquid extract (group $C$ ) and zinc oxide powder (group D), which performed on human gingival fibroblast culture-cells (3-5x103 densities) in 96 wells microplate. MTT essay was used to analyzed with IC50 parameters. Statistical analysis using oneway Anova and LSD. The number of living cells in group $A=64.819 \%$, group $B$ $=59.452 \%$, group $C=52.859 \%$ and group $D=60.502 \%$. There was no significant difference between the groups of $A, B, D$ but those groups were significantly different to group C. Combination of zinc oxide with Curcuma extract ratio of 1: 1 and 2: 1, zinc oxide powder and Curcuma liquid extract are not toxic to human gingival fibroblast at IC50.

Key words: Curcuma longa, cytotoxicity, zinc oxide

\section{PENDAHULUAN}

Salah satu manifestasi penyakit periodontal adalah gingival enlargement. Perawatan periodontal yang dapat dilakukan pada gingival enlargement adalah subgingival scaling dan supragingival scaling. Apabila setelah dilakukan scaling dan pembesaran gingiva tidak kunjung sembuh, maka dilakukan tindakan bedah periodontal yaitu gingivektomi atau periodontal flap. Tahap akhir dari tindakan bedah periodontal adalah pemberian periodontal dressing. Penggunaan dressing bertujuan untuk meminimalkan infeksi paska operasi, pendarahan dan membantu proses penyembuhan dengan cara melindungi permukaan luka selama pengunyahan, serta memberi perlindungan terhadap rasa sakit. Periodontal dressing umumnya terbuat dari seng oksida eugenol atau seng oksida non-eugenol. Kandungan eugenol pada periodontal dressing dapat menyebabkan reaksi alergi dengan warna kemerahan (iritasi) dan rasa terbakar pada daerah sekitar luka. ${ }^{1}$ Untuk menanggulangi sifat iritasi tersebut, dilakukan penelitian penggantian eugenol dengan ekstrak Curcuma longa. ${ }^{2}$ sebagai periodontal dressing alternatif.

Penelitian secara in vitro telah membuktikan bahwa campuran seng oksida dengan ekstrak Curcuma longa 1:1 dan 2:1 mempunyai sifat anti bakteri yang dapat menghambat pertumbuhan Streptococcus mutans. $^{3}$ dan Porphyromonas gingivalis. 4 yang menunjukan efektivitas terhadap bakteri rongga mulut. Keunggulan pemberian dressing campuran seng oksida dengan ekstrak Curcuma longa pada penelitian in vivo perbandingan 1:1, dapat mempercepat proses inflamasi. ${ }^{2}$ tetapi belum ada penelitian mengenai toksisitas dari bahan tersebut. Ada penelitian yang menyatakan bahwa seng oksida dalam keadaan tertentu dapat berpotensi toksik terhadap tubuh. Seng oksida larut dalam media, mengalami proses disosiasi, sehingga ion $\mathrm{Zn} 2+$ dapat merusak lisosom dan mitokondria, yang dapat menyebabkan kematian sel. ${ }^{5}$ Ekstrak Curcuma longa memiliki senyawa kurkuminoid. Kurkuminoid yang terkandung dalam kunyit mempunyai aktivitas yang sangat luas antara lain sebagai antioksidan, antihepatotoksik, antiinflamasi, antibakteri, antivirus, antijamur, dan antikoagulan. ${ }^{6}$ Berdasarkan latar belakang di atas penulis ingin melakukan uji sitotoksisitas kombinasi seng oksida dan ekstrak Curcuma longa terhadap sel fibroblas gingiva manusia.

Sel fibroblas banyak ditemukan pada jaringan ikat. Sel fibroblas gingiva manusia terlibat dalam mempertahankan matriks jaringan ikat, dan memiliki fungsi khusus dalam proses perbaikan sel, remodeling, serta regenerasi dari tulang alveolar dan cementum yang melekat pada gingiva. ${ }^{7}$ Metode yang biasa digunakan untuk uji sitotoksisitas adalah dengan uji enzimatik menggunakan pereaksi 3-(4,5-dimethylthiazol-2-yl)2,5diphenyl tetrazolium bromide (MTT), yaitu 
dengan melihat aktivitas enzim mitokondria secara fotometrik melalui reaksi perubahan warna, pewarna akan memberi warna selsel yang vital, sedangkan sel-sel dengan kerusakan membran tidak akan terwarnai. ${ }^{8}$ Penelitian ini bertujuan untuk mengetahui sitotoksisitas kombinasi seng oksida dan ekstrak Curcuma longa perbandingan 1:1 dan 2:1, juga bahan dasarnya, yaitu seng oksida dan ekstrak Curcuma terhadap sel fibroblas gingiva manusia.

\section{BAHAN DAN METODE}

Bahan: Bubuk seng oksida 99,8 \% (Merck Germany, cat 1.08849.0500). Ekstrak Curcuma longa cair, yang dimaserasi menggunakan etanol 96\% (Balai Materia Medica, Batu).

Metode: Penelitian eksperimental laboratoris ini merupakan post test only group design. Spesimen yang digunakan adalah bubuk seng oksida, ekstrak Curcuma longa cair dan kombinasi keduanya, yang dibagi dalam 4 kelompok. Spesimen A menggunakan bubuk seng oksida $0,1 \mathrm{~g}$ dan ekstrak Curcuma longa Linn $0,1 \mathrm{~g}$ (rasio $1: 1$ ). Spesimen $\mathrm{B}$ menggunakan bubuk seng oksida 0,2 g dan ekstrak Curcuma longa Linn 0,1 g (rasio 2:1). Spesimen $C$ menggunakan ekstrak Curcuma longa Linn cair dan spesimen D menggunakan bubuk seng oksida.

\section{Pembuatan Spesimen A dan B}

Spesimen dibuat dalam cetakan teflon diameter $5 \mathrm{~mm}$, tinggi $2 \mathrm{~mm}$, sisi dasar diberi matriks strip dan diletakkan di atas glass slab. Setelah bahan ditimbang, diaduk di atas mixing pad menggunakan spatula semen selama 60 detik hingga homogen, dimasukkan dalam cetakan menggunakan plastic filling instrument, ditunggu hingga setting selama 45 menit, baru kemudian dilepas.

\section{Tahap Persiapan Sampel}

Sepuluh spesimen masing-masing ditimbang 0,1 g dimasukkan ke dalam conical tube, ditambah $100 \mu \mathrm{L}$ media Alpha MEM disimpan selama 24 jam dalam lemari es. Media Alpha MEM hasil perendaman dikumpulkan dan disterilisasi menggunakan filter Milipore ukuran 0,2 $\mu \mathrm{m}$ dalam laminar flow. Hasil penyaringan ditampung dalam conical tube steril untuk digunakan sebagai sampel dalam uji sitotoksisitas setelah dilakukan pengenceran seri sampai dengan $5 \%$.

\section{Persiapan Sel Fibroblas Gingiva Manusia}

Proses splitting merupakan proses peremajaan dan memperbanyak sel yang diambil dari sel primer fibroblas gingiva manusia. Proses splitting dilakukan di Stem Cell Research Development Center Universitas Airlangga, Surabaya. Sel fibroblas monolayer dengan kondisi 80$90 \%$ dimasukkan ke dalam inkubator $\mathrm{CO} 2$. Selanjutnya media Alpha MEM yang ada di dalam petri dish dibuang. Sel fibroblas dicuci dengan PBS sebanyak 1 kali, ditambahkan trypsine EDTA pada petri dish, dimasukkan inkubator $\mathrm{CO} 2$ selama 5 menit dengan suhu 37o. Setelah sel fibroblas membulat dan terpisah, ditambahkan media Alpha MEM, dilakukan resuspensi menggunakan pipet aid, dimasukkan dalam conical tube ukuran 15 $\mathrm{mL}$ dan di centrifuge dengan kecepatan 1600 rpm selama 5 menit. Supernatan dibuang, sel fibroblas dalam media kultur Alpha MEM dilakukan resuspensi menggunakan pipet aid, dimasukkan ke dalam petri dish dan disimpan di dalam inkubator $\mathrm{CO} 2$ dengan suhu 370C selama 24 jam. Sel fibroblas gingiva manusia di dalam petri dish diamati menggunakan mikroskop inferted, kemudian disimpan dalam inkubator $\mathrm{CO} 2$.

\section{Tahap pengujian sitotoksisitas}

Microplate 96 well disiapkan. Well pada kolom ke-1 dan kolom ke-8 microplate diisi media kultur Alpha MEM menggunakan mikropipet sebanyak $150 \mu \mathrm{L}$ sebagai kontrol media, dianggap persentase sel hidup $100 \%$. Well pada kolom ke-2 hingga ke-7 yang diisi $100 \mu \mathrm{L}$ sel fibroblas gingiva manusia (kepadatan sel 3-5 x 103) dalam media kultur Alpha MEM. Well pada kolom 2 dan 7 merupakan kontrol sel, dianggap persentase sel hidup $0 \%$. Well pada kolom 3 hingga 6 ditambahkan $150 \mu \mathrm{L}$ cairan sampel sesuai kelompok. Microplate diinkubasi dalam inkubator $\mathrm{CO} 2$ dengan suhu 370 selama 24 
jam.

Serbuk MTT dilarutkan dalam Phosphate Buffered Saline $10 \%$ sebanyak $5 \mathrm{mg} / \mathrm{mL}$. Larutan MTT ditambahkan sebanyak $10 \mu \mathrm{L}$ pada setiap well, kemudian dimasukkan dalam inkubator $\mathrm{CO} 2$, suhu $370 \mathrm{C}$ selama 4 jam. Seluruh media dan bahan uji dibuang, kemudian ditambahkan $50 \mu \mathrm{L}$ Dimethyl Sulfoxide (DMSO) setiap well. Nilai optical density formazan dihitung menggunakan ELISA reader dengan panjang gelombang $595 \mathrm{~nm}$. Makin pekat warnanya, makin tinggi nilai absorbansinya maka semakin banyak jumlah sel fibroblas gingiva manusia yang hidup.

Persentase sel hidup dihitung dengan rumus: $\%$ Sel Hidup $=$ Persentase jumlah kehidupan sel setelah perlakuan

$\mathrm{OD}$ Perlakuan $=$ Nilai $\mathrm{OD}$ (optical

density) formazan setiap sampel setelah pengujian

OD Media = Nilai OD (optical density) formazan pada rerata setiap kontrol media OD Kontrol sel= Nilai OD (optical density) formazan pada rerata kontrol sel

\section{HASIL}

Hasil pengamatan dan perhitungan mengenai uji sitotoksisitas kombinasi seng oksida dan ekstrak Curcuma longa terhadap sel fibroblas gingiva manusia, dapat dilihat pada tabel 1

Tabel 1. Besar sampel, rerata, standar deviasi dan persentase sel hidup

\begin{tabular}{|c|c|c|c|c|}
\hline $\begin{array}{c}\text { Kelom- } \\
\text { pok }\end{array}$ & $\mathrm{n}$ & \multicolumn{3}{|c|}{ Rerata } \\
\cline { 3 - 5 } & & $\mathrm{OD}$ & $\mathrm{SD}$ & $\begin{array}{c}\text { Sel } \\
\text { Hidup }\end{array}$ \\
\hline $\mathrm{A}$ & 4 & 0,315 & 0,012111 & 64,819 \\
\hline $\mathrm{B}$ & 4 & 0,292 & 0,005099 & 59,452 \\
\hline $\mathrm{C}$ & 4 & 0,263 & 0,004856 & 52,859 \\
\hline $\mathrm{D}$ & 4 & 0,296 & 0,007937 & 60,502 \\
\hline $\begin{array}{c}\text { Kontrol } \\
\text { Sel }\end{array}$ & 4 & 0,465 & 0,004573 & 100,00 \\
\hline $\begin{array}{c}\text { Kontrol } \\
\text { media }\end{array}$ & 4 & 0,037 & 0,000957 & 0,00 \\
\hline
\end{tabular}

Keterangan:

A = Kombinasi seng oksida dan ekstrak Curcuma longa 1:1
B = Kombinasi seng oksida dan ekstrak Curcuma longa 2:1

C = Ekstrak Curcuma longa

$\mathrm{D}=$ Seng oksida

$\mathrm{n} \quad=$ Besar sampel

$\mathrm{OD} \quad=$ Optical density

$\mathrm{SD}=$ Standar deviasi

Uji normalitas distribusi dilakukan menggunakan Kolmogrov-Smirnov didapatkan nilai $0,964(p>0,05)$, dilanjutkan dengan uji homogenitas menggunakan Levene test didapatkan hasil 0,684 $(p>0,05)$. Data yang berdistribusi normal dan homogen, merupakan syarat untuk uji parametrik oneway Anova. Uji Anova didapatkan signifikansi $0,000 \quad(p<0,05)$, terdapat perbedaan signifikan pada kelompok sampel. Untuk mengetahui kelompok yang berbeda, maka dilanjutkan dengan uji Least Significant Difference (LSD), yang dapat dilihat pada tabel 2.

Tabel 2. Uji LSD terhadap sel fibroblas gingiva manusia

\begin{tabular}{|c|c|c|c|c|}
\hline $\begin{array}{c}\text { Kelom- } \\
\text { pok }\end{array}$ & $\mathbf{A}$ & $\mathbf{B}$ & $\mathbf{C}$ & $\mathbf{D}$ \\
\hline $\mathrm{A}$ & - & 0,100 & $0,000^{*}$ & 0,638 \\
\hline $\mathrm{B}$ & & - & $0,000^{*}$ & 0,738 \\
\hline $\mathrm{C}$ & & & & $0,001^{*}$ \\
\hline $\mathrm{D}$ & & & & - \\
\hline
\end{tabular}

Keterangan:

$*$ = Perbedaan signifikan

$A=$ Kombinasi seng oksida dan ekstrak

Curcuma longa 1:1

$\mathrm{B}=$ Kombinasi seng oksida dan eksrak Curcuma longa 2:1

$C=$ Ekstrak Curcuma longa

$D=$ Seng oksida

\section{PEMBAHASAN}

Setiap bahan yang digunakan dalam bidang kedokeran gigi harus memenuhi syarat biokompatibilitas. Salah satu syarat biokompatibilitas adalah bahan yang akan digunakan bersifat tidak toksik terhadap jaringan tubuh. Uji sitotoksisitas adalah tahap awal dari uji biokompatibilitas. $\mathrm{Uji}$ sitotoksisitas dilakukan untuk menentukan 
apakah suatu material mengandung bahan yang berbahaya secara biologis terhadap jaringan tubuh, sebelum bahan tersebut dapat digunakan. ${ }^{9}$ Parameter yang digunakan pada penelitian ini adalah parameter Inhibitory Concentration 50\% (IC50). Parameter IC50 merupakan konsentrasi suatu bahan yang mampu menghambat proliferasi sel hingga $50 \%$ dari populasi. ${ }^{10}$ Persentase sel fibroblas gingiva manusia yang masih hidup setelah diberi perlakuan dapat menunjukkan tingkat toksisitas dari setiap kelompok sampel. Jika bahan yang dipaparkan tidak bersifat toksik, maka dehidrogenase akan aktif sehingga akan terproduksi kristal formazan. ${ }^{11}$ Apabila kristal formazan diproduksi, maka sel fibroblas akan terwarnai menjadi biru keunguan. Sel yang hidup akan terwarnai, sedangkan sel dengan kerusakan membran tidak akan terwarnai. ${ }^{12}$

Hasil uji sitotoksisitas (Tabel 1) dapat dilihat bahwa sel hidup fibroblas gingiva manusia dengan nilai lebih dari 50\% terdapat pada semua kelompok. Hal ini menunjukkan bahwa seng oksida, ekstrak Curcuma longa dan kombinasinya tidak bersifat sitotoksik terhadap sel fibroblas gingiva manusia. Hasil analisis data oneway Anova menunjukkan bahwa terdapat perbedaan signifikan pada kelompok sampel. Hal tersebut menunjukkan ada perbedaan sitotoksisitas diantara kelompok. Perbedaan hasil sitotoksisitas tersebut dipengaruhi oleh kandungan yang terdapat dalam masing-masing bahan. Hasil analisis data penelitian dengan uji LSD (tabel 2) dapat diketahui bahwa jumlah sel fibroblas gingiva manusia yang hidup pada kelompok A $(64,819 \%)$ tidak berbeda signifikan dengan kelompok B $(59,452 \%)$, dan kelompok $D(60,502)$. Hal ini kemungkinan disebabkan adanya kandungan seng oksida pada kelompok tersebut, meskipun ada penelitian yang menyatakan seng oksida dalam keadaan tertentu berpotensi toksik ${ }^{5}$ Seng oksida memiliki peranan penting dalam mengendalikan apoptosis, yang membuat sel fibroblas dapat bertahan hidup lebih lama. Terdapat dua fungsi antiapoptotik $\mathrm{Zn} 2+$ dapat mencegah terganggunya proses oksidasi dan kerusakan yang disebabkan oleh toksin dengan bertindak langsung pada regulator apoptosis terutama pada enzim yang termasuk famili caspase. Mengurangi kerusakan yang disebabkan oleh toksin dengan mencegah terjadinya proses apoptosis melalui penghambatan aktivitas induksi caspase yang dipicu saat konsentrasi Zn2+ intraselular menurun. ${ }^{13}$

Kelompok A, B, D berbeda signifikan dengan kelompok $C$. Persentase sel hidup pada kelompok C, lebih rendah, hanya sebesar $52,859 \%$ atau dapat diartikan mendekati sitotoksik dibandingkan dengan kelompok lain. Hasil uji laboratoris di Unit Layanan Pengujian Kampus B Universitas Airlangga menyatakan bahwa, ekstrak Curcuma longa yang digunakan dalam percobaan ini mengandung $36,876 \%$ kurkuminoid, yang terdiri dari kurkumin, desmetoksikurkumin, dan bis-desmetoksi-kurkumin. Kandungan senyawa aktif kurkuminoid dapat mempercepat proses inflamasi, sebagai anti oksidan yang dapat menghambat ROS (Reactive Oxygen Species) dan seharusnya tidak menyebabkan kematian sel pada keadaan sel normal. ${ }^{14}$ Efek ekstrak Curcuma longa Linn sampai dengan dosis $200 \mathrm{mg} /$ kgBB selama 31 hari tidak menyebabkan toksik pada hati tikus Wistar. ${ }^{15}$ Persentase sel hidup fibroblas gingiva manusia yang rendah pada kelompok $\mathrm{C}$, kemungkinan karena faktor dosis yang diberikan pada selapis sel primer fibroblas gingiva manusia terlalu besar. Mekanisme kurkumin menginduksi terjadinya apoptosis sangat bervariasi, dan diduga melalui penghambatan beberapa cellsignaling pathway. Penelitian terdahulu juga melaporkan bahwa kurkumin menyebabkan kematian sel sebanyak separuh dari jumlah sel yang diinduksinya, meskipun mekanismenya belum jelas. ${ }^{16}$ Kematian sel dapat dipengaruhi oleh sifat dari suatu bahan kemurnian, struktur kristal, komposisi kimia, media yang digunakan dan kelarutan atau kemampuan bahan melepaskan suatu ion. ${ }^{17}$

\section{SIMPULAN}

Hasil penelitian yang telah dilakukan dapat disimpulkan kombinasi seng oksida dan 
ekstrak Curcuma longa 1:1 dan 2:1 bersifat tidak toksik terhadap sel fibroblas gingiva manusia pada IC50.

\section{DAFTAR PUSTAKA}

1. Klokkevold PR, Takei H, Carranza FA. General principles of periodontal surgery. In: Newman M, Takei $H$, Klokkevold $P$, Carranza F, editors. Carranza's Clinical Periodontology. 12th ed. St. Louis: Elsevier Saunders; 2015:569-72.

2. Meizarini A, Siswandono, Yuliati A. The role of TLR2, NF-KB, TNFa as an inflammation markers of wound dressing combination of zinc oxide with turmeric liquid extract. J Int Dent Med Res 2016; $91732016 ; 177$.

3. Indrastie N, Yogyarti S, Meizarini A. Daya hambat campuran Zinc oxide dengan ekstrak Curcuma longa Linn terhadap Streptococcus mutans. Dent J (Maj Ked Gigi) 2015;6:58-54.

4. Jessica NF, Yogyarti S, Meizarini A. Daya hambat campuran Zinc oxide dengan ekstrak Curcuma longa Linn terhadap pertumbuhan bakteri phorphyromonas gingivalis. Dent J (Maj Ked Gigi) 2016;7:61-5.

5. Xia $T$, Kovochich $M$, Liong $M$, Mädler $L$, Gilbert B, Shi $H$, et al. Comparison of the mechanism of toxicity of zinc oxide and cerium oxide nanoparticles based on dissolution and oxidative stress properties. ACS Nano 2008;2:2121-34.

6. NMandroli PS, Bhat K. An in-vitro evaluation of antibacterial activity of curcumin against common endodontic bacteria. J Appl Pharm Sci 2013;3:16.

7. Zhang Q, Shi S, Liu Y, Uyanne J, Shi Y, Shi $S$, et al. Mesenchymal stem cells derived from human gingiva are capable of immunomodulatory functions and ameliorate inflammation-related tissue destruction in experimental colitis. J Immunol 2009;183:7787-98.

8. Mueller $\mathrm{H}$, Kassack $\mathrm{MU}$, Wiese $M$. Comparison of the usefulness of the MTT, ATP, and calcein assays to predict the potency of cytotoxic agents in various human cancer cell lines. J Biomol Screen
2004;9:506-15.

9. Swetha B, Mathew S, Murthy B V, Shruthi N, Bhandi SH. Determination of biocompatibility: A review. Int Dent Med J Adv Res 2015;1:1-6.

10. Nevozhay D. Cheburator software for automatically calculating drug inhibitory concentrations from in vitro screening assays. PLoS One 2014; 9:e106186.

11. Ariani MD, Yuliati A, Adiarto T. Toxicity testing of chitosan from tiger prawn shell waste on cell culture. Dent J (Majalah Kedokt Gigi) 2009;42:15-20.

12. Schmalz G, Arenholt-Bindslev D. Biocompatibility of Dental Materials. Vol 1. Springer; 2009.

13. John E, Laskow TC, Buchser WJ, Pitt BR, Basse $\mathrm{PH}$, Butterfield $\mathrm{LH}$, et al. Zinc in innate and adaptive tumor immunity. J Transl Med 2010;8:118.

14. Syng-ai C, Kumari AL, Khar A. Effect of curcumin on normal and tumor cells: role of glutathione and bcl-2. Mol Cancer Ther 2004;3:1101-8.

15. Maharani HW, Saiful MS. Subchronic effect of tumeric rhizome (Curcuma longa Linn) on rat liver. Media Farm $2015 ; 12: 213-22$.

16. Hutomo S, Susilowati H, Suryanto YI, Kurniawan C. Perubahan morfologi sel HeLa setelah paparan ekstrak etanolik Curcuma longa. Maj Kedokt Gigi Indones 2017;2:1-5.

17. Djurišić $A B$, Leung $Y H, N g \quad A M C$, $\mathrm{Xu} X Y$, Lee $\mathrm{PKH}$, Degger $N$, et al. Toxicity of metal oxide nanoparticles: mechanisms, characterization, and avoiding experimental artefacts. Small $2015 ; 11: 26-44$ 